LUIS CARRAL, Ph.D. ${ }^{1}$

(Corresponding author)

E-mail: Icarral@udc.es

JAVIER TARRÍO-SAAVEDRA, Ph.D. ${ }^{1}$

E-mail: jtarrio@udc.es

LAURA CASTRO-SANTOS, Ph.D. ${ }^{1}$

E-mail: laura.castro.santos@udc.es

ISABEL LAMAS-GALDO, Ph.D. ${ }^{1}$

E-mail: Isabel.lamas.galdo@udc.es RODOLFO SABONGE, Ph.D. ${ }^{2}$

E-mail: rodosabochamo@gmail.com

${ }^{1}$ EPS Ferrol, University of La Coruña

Campus de Esteiro, Rúa Mendizábal s/n, 15403 Ferrol, España

2 Ancon-Balboa-Ciudad de Panamá, International Maritime University of Panamá La Boca, Edif. 1033, Corregimiento de Ancón, Panamá, P.O. Box 0843-03561, Panama
Traffic Infrastructure

Review

Submitted: 7 Feb. 2017

Accepted: 23 Nov. 2017

\title{
EFFECTS OF THE EXPANDED PANAMA CANAL ON VESSEL SIZE AND SEABORNE TRANSPORT
}

\begin{abstract}
The Panama Canal (PC) expansion will have an impact on trading patterns and the manner in which goods are transported around the world. Once the third set of locks at the Canal began their operation, it was clear that the way in which vessels transited the canal and their maximum dimensions were going to change. As such, the expanded Canal will undoubtedly mean that a new kind of vessel will come into existence. In terms of dimensions, these Neopanamax ships will be adapted to how the locks operate. However, this effect will not be the same across the full range of traffic. After the first transit on 26 June 2016, it was possible to obtain access to transit data for Neopanamax ships. A thorough statistical study of these new datasets would involve analysing how these new locks impact the vessel size and seaborne transport.
\end{abstract}

\section{KEY WORDS}

Panama Canal expansion project; ships; statistical learning; seaborne trade; market segment;

\section{INTRODUCTION}

The construction of the Panama Canal at the beginning of the last century transformed international commerce by opening up new routes between the countries which previously had no trade relations due to the distances involved. The Canal was originally constructed for military purposes [18]; however, over time it has become a catalyst for international trade by reducing transport times and distances, which has led to increased competitiveness for many countries and regions [33].

The expansion work began in 2007, and since then, as was to be expected, international trade has continued to change. Economic factors, including demand, have impact on the Canal traffic. However, what is important for Panama is not the increase or decrease in the global trade overall, but the increase in the shipping related to the Canal [33].

The original PC covered a distance of $65 \mathrm{~km}$ across the Isthmus of Panama. Its primary function was to facilitate transit through a single canal complex with a double set of three locks (Miraflores, Gamboa and Gatún) [14]. By means of these locks it was possible to raise vessels to the level of the Gatún Lake and then lower them again to the level of the other ocean. A navigational channel was literally cut through the centre of the country, and a watershed provides the water to keep lake levels and the depth which allow safe transit of the vessel in accordance with their drafts [19].

The two main interoceanic canals, the Suez and Panama, play crucial roles in the flow of maritime traffic. Ducruet C. [13] has accurately measured their importance in terms of geographic coverage and the network comprising the topological properties of the canal-dependent flows. Table 1 reveals how important the PC is in terms of total flow of container movement. On the other hand, the paper by Notteboom and Rodrigue [26] estimates that the participation of the PC in total maritime trade is around $5 \%$. 
Table 1 - Importance (in percentages) of the PC and the Suez Canal in terms of combined flow of container movement [13]

\begin{tabular}{||l|c|c|c|c|c|c||}
\hline \multirow{2}{*}{} & \multicolumn{2}{|c|}{ Panama Canal } & \multicolumn{2}{c|}{ Suez Canal } & \multicolumn{2}{c||}{ Panama and Suez } \\
\cline { 2 - 7 } & 1996 & 2006 & 1996 & 2006 & 1996 & 2006 \\
\hline \hline Total traffic & 17.0 & 13.3 & 34.0 & 30.8 & 44.2 & 40.7 \\
\hline Intra-regional traffic & 10.7 & 8.0 & 24.6 & 21.8 & 31.8 & 27.8 \\
\hline Inter-regional traffic & 26.8 & 23.1 & 48.8 & 47.6 & 63.7 & 64.4 \\
\hline
\end{tabular}

Due to the principle of economies of scale, vessels have increased in size so that seaborne trade could become more competitive [12, 34]. As result, the PC had to be well maintained in order to meet these needs [28]. In Table 1, one can observe a decrease in PC transits over one decade. As a result of this trend, a tripartite entity, comprising Japan, the USA and Panama, was created in 1985 to look at the options for the Canal [23].

The Canal expansion project was delayed. This meant that there was more time to produce a range of studies on how these modifications would have an impact on shipping. In terms of traffic, Sabonge R. [33] indicated that the change would affect a huge geographical area: the Pacific Asia, North and South America, as well as the European Union. One route would be especially affected: the movement of containers between Asia and the USA. Lindstad et al. [20] emphasised the fact that by using the PC it was possible to avoid long distance routes like Suez and Cape Horn. With distances reduced, there would also be a decrease in sea miles and in the emission of $\mathrm{CO}_{2}$ and other contaminants.

Ungo and Sabonge, [35] analysed the relative competitiveness of the Panama Canal route in comparison with alternatives. They looked at a range of general voyage costs and scenarios for other relevant cost variables. Rodrigue and Ashar, [31] and Guevara-Martinez, [16] predicted that with the expanded canal another type of vessel would come into existence: Neopanamax ships.
Analysing the traffic of liquid natural gas (LNG), Moryadee et al. [24] stated that the role played by the Canal as a link between two maritime areas, the Atlantic and the Pacific, would have a great impact globally as each of these areas represents a distinct reality for the gas market.

However, most studies focus on how the project would have an impact on ports. Pagano et al. [28], Mitchell [22] and Cope III et al. [10] studied the effect that would be experienced by ports along the eastern and southern coasts of the USA. At the same time Pagano et al. [27] determined how Caribbean ports, as a stopover point for vessels on their way to/from the USA, would be altered. Another study [28] looked at how Panama's maritime cluster would be affected.

Once the third set of locks at the PC began with operation, it was clear that the way in which vessels transited the Canal and their maximum dimensions were going to change. The increase in vessel size meant new operational routes would come into service. As such, the aim of this study is to analyse how the newly expanded Canal will affect vessels and seaborne trade.

\section{THE SOLUTION CHOSEN: EXPANDING THE CANAL}

Expanding the canal meant building a third set of locks larger than the ones constructed in 1914. This work went hand in hand with other measures, outlined in Figure 1. These are the main features of the expansion project.

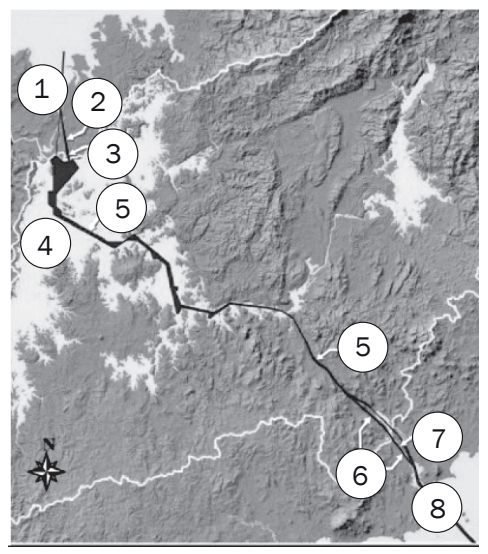
1 - Deepening and widening the access channel to the Atlantic
2 - New access channel for the Post-Panamax locks on the Atlantic side
3 - Post-Panamax locks on the Atlantic
4 - Increasing the water level at the Gatún Lake
5 - Widening and deepening the navigation channels on the Gatún Lake and deepening the Culebra Cut
6 - New access channels to the Post-Panamax locks on the Pacific side
7 - Post-Panamax locks on the Pacific
8 - Deepening and widening the access channel to the Pacific

Figure 1 - Project to expand the existing Canal [3] 
A set of locks is located on the Atlantic side of the Canal, on the east bank of the Gatún locks (Figure 2). Another set of locks is located on the Pacific side, to the southwest of the Miraflores locks (Figure 3). The chambers of these new locks are $426.7 \mathrm{~m}$ long, 54.9 $\mathrm{m}$ wide and $18.3 \mathrm{~m}$ deep. Ungo and Sabonge [35] indicate that to determine the chamber size for the new

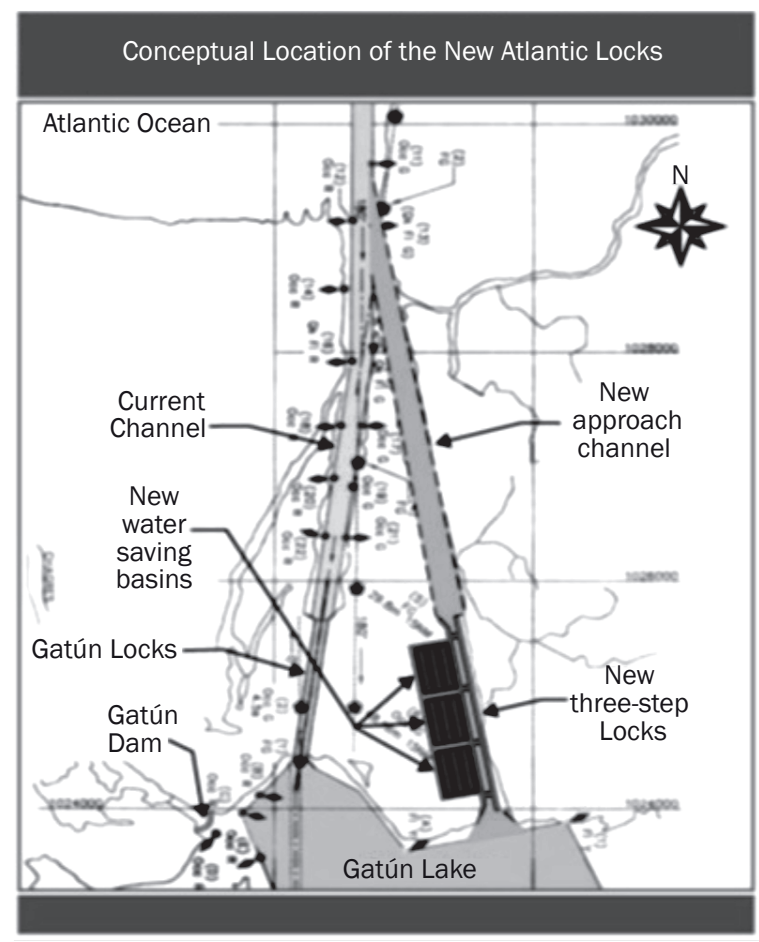

Figure 2 - A set of locks on the Canal's Atlantic side [3]

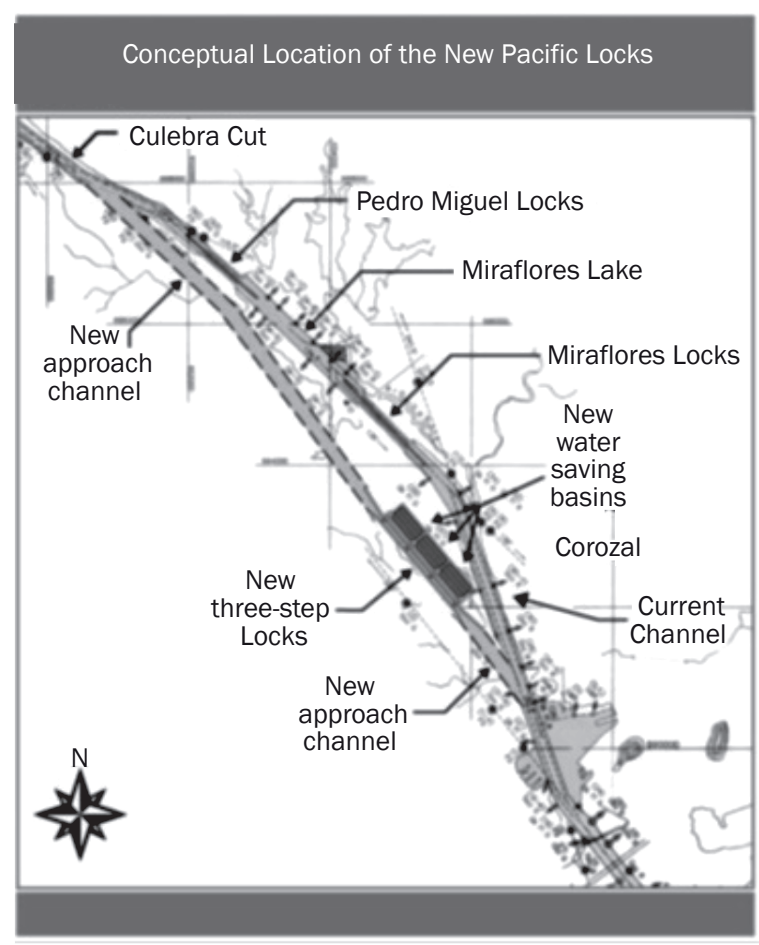

Figure 3 - A set of locks on the Canal's Pacific side [3] locks, a container ship was used as a point of reference, given the importance of this traffic to income from the Canal transit tolls (higher than $50 \%$ of the total). Dimensions of $366 \mathrm{~m}$ (length), $49 \mathrm{~m}$ (beam) and $15.1 \mathrm{~m}$ (maximum draft) in tropical fresh water correspond to the dimensions of the largest Post-Panamax ship that will be able to use the expanded Canal (ACP, 2006. Ch. 6, p. 20) [3].

Nevertheless, there is a possibility that the beam of this vessel could rise above $49 \mathrm{~m}$ for a vessel designed to carry 14,100 TEU, once the locks' operating system becomes fully operable [30].

When it was time to choose the best type of gates for the new locks, it was decided that a sliding model was the most suitable (PCA, 2006. Ch. 6, p. 24) [3]. As was the case with the gates already in use, new locks would have redundancy to allow for maintenance at each end of the chambers (Figure 4).

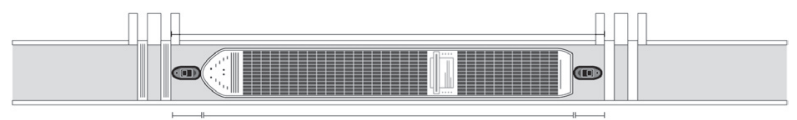

Figure 4 - Layout of a lock in the expanded Canal with the location of the double sliding gates and the tugs in position [8]

The key factor is how vessels are positioned within the lock chambers. These systems had to be able to efficiently manoeuvre the Neopanamax vessels within the locks. At the same time, the systems had to be suitably flexible so that Panamax and a variety of smaller vessels could also transit through them.

In the end, the system selected involves positioning the vessels by means of tugboats located in the interior of the lock with the ship [8]. As such, the total available length is reduced given that it is necessary to take into account the space occupied by the tugs to the front and rear of the ship.

\section{EFFECT ON SEABORNE TRADE}

The Canal expansion will have an impact on maritime trade and on the routes by which goods are transported around the world. However, unlike what occurred in 1914, when the new Canal opened up the previously unimaginable trade routes, it is now the Canal itself which is adapting to changes in the maritime industry [33]. Once the expansion is operational, it will be useful to analyse the effects on traffic and thus evaluate the changes in maritime transport brought about by the Canal expansion.

Four types of ships make up the greater part of transport traffic through the Panama Canal: (a) container ships, (b) bulk carriers, (c) a range of vessels comprising oil, chemical and gas carriers transporting liquid bulk cargo, and finally (d) refrigerated cargo ships (Figure 5). Combined, these fleet segments 


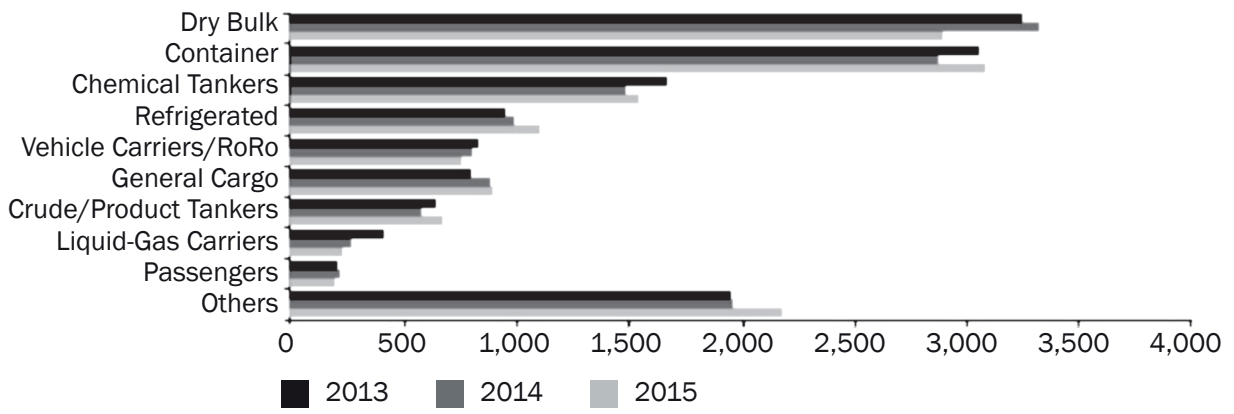

Figure 5 - Traffic transiting the Canal over the years 2013, 2014, 2015 [6]

represent nearly $80 \%$ of the number of transits and income from tolls (Table 2), as well as over $90 \%$ of cargo tonnage transported through the Canal $[30,6]$.

Figure 5 shows a bar chart representing traffic transiting the Canal over the past three years $(2013,2014$, 2015). Container ships and bulk carriers lead in the statistics in terms of transits. In this regard, it is worth mentioning that there is great deal of fluctuation in the transit of dry bulk goods, as these depend on varying annual weather conditions. Next are chemical tankers, refrigerated cargo ships, Ro-ro, general cargo, oil and gas tankers and passenger ships.

\subsection{Routes and traffic affected}

\section{Container ships}

For container ship traffic through the Canal (Figure 6), the main routes are between Asia and the East Coast of the USA, and the latter and the west coast of South America. Of these, the first route is more important and accounts for $44 \%$ of the total cargo transported on container ships through the Canal [6]. In the analysis of the effects on these routes, it is necessary to take into account that the new locks will permit passage by Neopanamax ships, a ship size which currently represents $47 \%$ of the existing fleet [29]. In view of this, by applying the economies of scale, this will mean an improvement in price competitiveness of the all-water route (Panama Canal) compared to using the American Intermodal System [30].

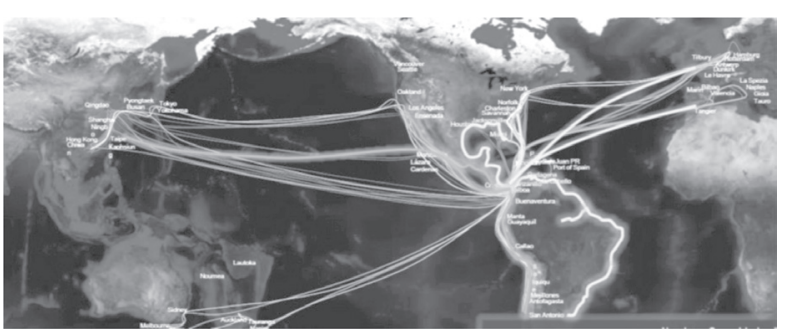

Figure 6 - Container ships: various regular shipping lines affected by transit through the Canal
The expansion of the container ships beyond the Neopanamax size in the most recent ship construction has led the PCA (Panama Canal Authority) to adopt the necessary provisions in order to be able to meet the challenges involved in designing the fourth set of locks [1].

\section{Dry bulk cargo}

Every year nearly $50 \%$ of grain exports from the USA are sent to the markets in Asia and use the Panama Canal route [6]. With the Canal expansion, and taking into account the draft depth limits in the ports of origin, the American exporters can send cargo in ships of up to 95,000 tonnes deadweight (DWT). Similarly, the Brazilian exporters will be able to send shipments of soya beans to Asia leaving from ports located in the northeast of Brazil [33].

Sabonge [33] points out the possibility of seeing Capesize ships setting sail for China from terminals in Newport News/Hampton Roads, Virginia, given that these have a draft depth of 50 feet. Ships would save up to 13 days in transit time compared to the alternative route via the Cape of Good Hope. Similarly, Riva [30] analyses the possibility that Colombia might improve its foreign trade by exporting coal through the expanded Canal in Capesize ships of limited draft. The route through Panama would allow savings of 15 days in transit time for ships originating in Puerto Bolivar and destined for China.

There is also a possibility of iron ore exports originating in Brazil to destinations in Asia by using bulk carriers of up to 120,000 DWT, which may be a possible alternative to using Capesize ships or VLBCs (Very Large Bulk Carriers) on the Cape of Good Hope route [30].

\section{Liquid bulk cargo}

The transit of natural gas (LNG) through the Canal is a recent development (Table 2), which has come about due to the current imbalance between the production and consumption in the Atlantic and the Pacific maritime areas [24].

Due to the use of fracking extraction technology, within a few years the USA will go from being an energy importing country to becoming a net energy exporter. 
As such, while there is an increase in the production in the Atlantic area, in Asia the consumption is also increasing as result of the growth in emerging economies as well as the post-Fukushima energy diversification policies pursued in Japan. In response to the demand for transport, supply is being addressed via a fleet of gas tankers made up primarily of Post-Panamax ships. The consequences are clear. For the first time it will become possible to ship LNG through the Canal from the Gulf of Mexico (USA) (Figure 7) to Asia [32]; [33]. The recent development of fields in Peru, Trinidad and Tobago, Bolivia and Venezuela allows the option of transiting the Canal to reach their principal destinations, which may be Asia or Europe (Figure 8).

The Venezuelan exports to Asia could transit the expanded Canal by using limited draft Suezmax ships, though this would face stiff competition from the Cape of Good Hope route [30]. Another alternative for the Venezuelan crude would be to reach the west coast of the USA using Aframax ships due to the draft limitations in the destination ports. With regard to Ecuador (the fourth largest exporter in Latin America after Mexico, Venezuela and Brazil), the deliveries to the east coast of the USA could be made using Aframax ships [33].

\section{Refrigerated cargoes}

Two deciding factors influence the prospects for this subcategory of general cargo traffic with respect to transiting the expanded Canal. On the one hand is the fact that the size of current ships involves dimensions smaller than a Panamax vessel. On the other hand, there is the ongoing migration of cargo to transport by refrigerated container ships [33], which inhibits the

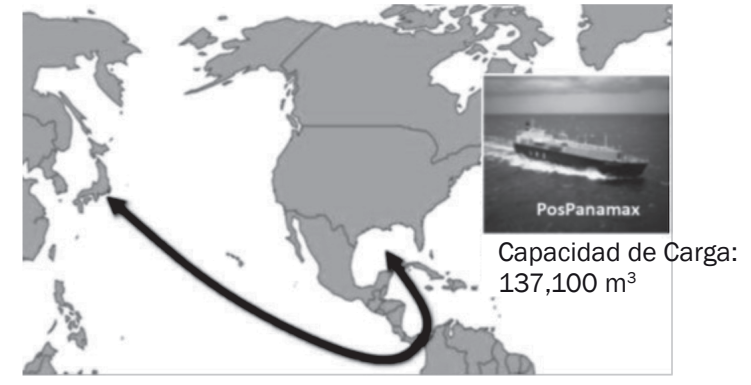

Figure 7 - LNG route: originating in the USA, loaded in the Gulf of Mexico, and destined for Asia

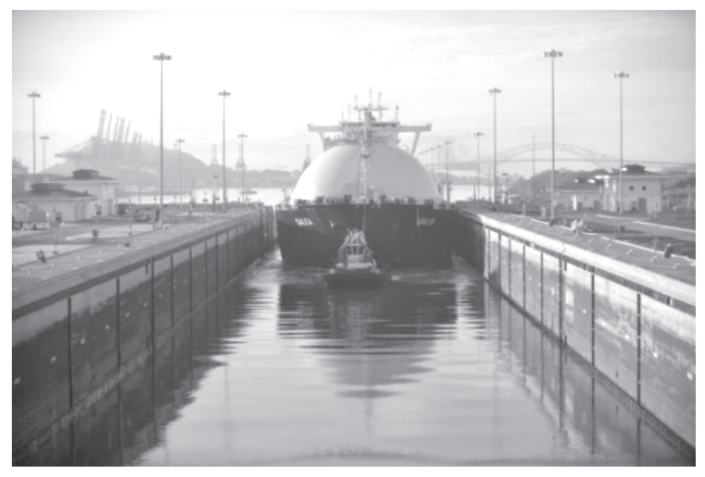

Figure 8 - Galea, the first Kvaerner Moss type LNG carrier, transiting the Canal 26/08/2016. Source: PCA

fleet renewal process from leading to an increase in ship size, which in return results in the aging of the fleet.

\subsection{Transits completed during the first months of the expanded Canal's operation}

After the third set of locks was placed in service in June 2016, the transit of Neopanamax ships through the Canal began. Table 2 and Figure 9 have been

Table 2 - Total transit traffic through the original Canal for the years 2015 and 2016 and traffic data for the expanded Canal (2016) for the five months following its inauguration

\begin{tabular}{||l|c|c|c|c||}
\hline \multicolumn{1}{|c|}{ Traffic } & $\begin{array}{c}\text { Original Canal } \\
\text { Traffic distribution 2015 } \\
{[\%]}\end{array}$ & $\begin{array}{c}\text { Traffic distribution 2016 } \\
{[\%]}\end{array}$ & $\begin{array}{c}\text { Transits } \\
\text { 2016 (5 months) } \\
\text { [number of ships] }\end{array}$ & $\begin{array}{c}\text { Traffic distribution } 2016 \\
{[\%]}\end{array}$ \\
\hline \hline Bulk carriers & 32.1 & 27 & 5 & 1.33 \\
\hline Container ships & 23.5 & 26.2 & 31.6 \\
\hline Oil tankers (1) & 17.5 & 17.7 & 26 & 0.8 \\
\hline LNG & 0 & 0 & 98 & 0.93 \\
\hline LPG & 2.1 & 3.3 & 12 & 0 \\
\hline Refrigerated & 6.6 & 7.4 & 0 & 3.2 \\
\hline Ro-ro & 6.2 & 6.8 & 0 & 0 \\
\hline General cargo & 7.2 & 7.4 & 0 & 0 \\
\hline Cruises & 1.4 & 1.2 & 375 & 100 \\
\hline Others & 3.4 & 100 & & 0 \\
\hline Total & 100 & & 0 & 0 \\
\hline
\end{tabular}

Source: Author, based on [6], includes chemical tankers 
constructed using transit data for the first five months of the expanded Canal's operation and figures for the last two years (2015 and 2016) for the original Canal.

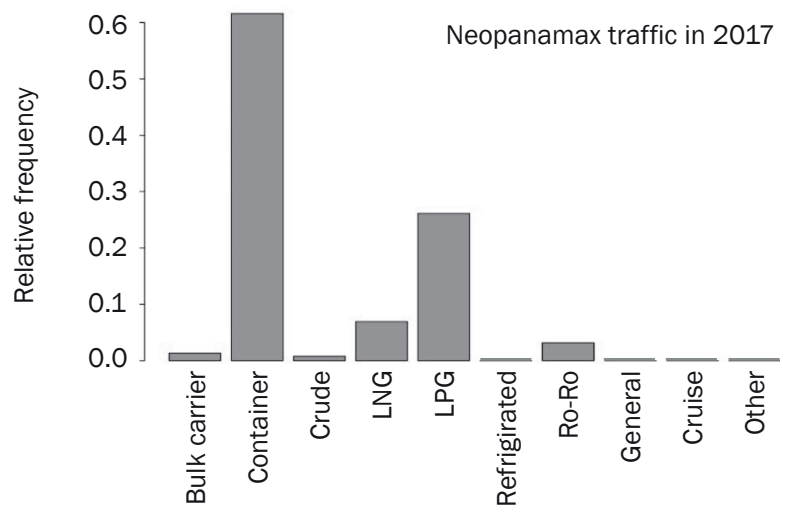

Figure 9 - Relative transit frequency for Neopanamax ship types through the expanded Canal

\subsection{Statistical analysis of transits through the expanded Canal}

The first part of the data analysis contained in Table 2 refers to transits by traffic and the year in which they occur in the original Canal for 2015 and 2016. Note that Figure 10 shows the "association plot" for the variables ship type and transit year and it was created using "R" statistical software [17]. The association diagram proposed by Cohen [9] (1980) shows the standard deviations for the frequencies observed versus the frequencies expected under the null hypothesis. Each cell is represented by a rectangle with a height proportional to the Pearson standardised residual (test of independence) and a width proportional to the square root of the count expected for each combina- tion of variables. As such, the area of each rectangle is proportional to the difference between the frequencies observed and expected, i.e., the larger the rectangles, the more dependent the variables studied. In this scenario, the null hypothesis is that the type of ship and the year of transit are independent variables. Figure 10shows that this assumption is notsubstantiated ( $p$-value $<0.01$ ), particularly for transits by oil tankers and bulk carriers. The greatest positive differences appear in blue, while the greatest negative differences are shown in red. This confirms that the number of transits by bulk carriers is significantly lower in 2016 than in 2015, whereas oil tanker traffic is significantly higher in 2016. The same trend can be observed for LNG carriers. With respect to the remainder of ships, the number of transits in 2016 is not significantly different from the number of transits in 2015.

The second part of the analysis in Table 2 seeks to establish whether the traffic distribution by segments in the expanded Canal differs from what was recorded in recent years for the original Canal. For this purpose, Figure 11 was constructed to show the "association plot" for the variables ship type and canal transited (original or expanded) and it was created using "R" statistical software [17]. In this scenario, the null hypothesis is that ship type and canal transited are independent variables. Figure 11 shows that this assumption is not substantiated ( $p$-value of the chi-square test $<0.01$ ). In particular, the number of transits is different (with statistical significance) in the original and expanded canals for all types of ships studied. The greatest differences with respect to the independence hypothesis were obtained for Bulk carrier, Container, Crude, LNG and LPG vessel types. This confirms that the number of transits for container, LNG and LPG

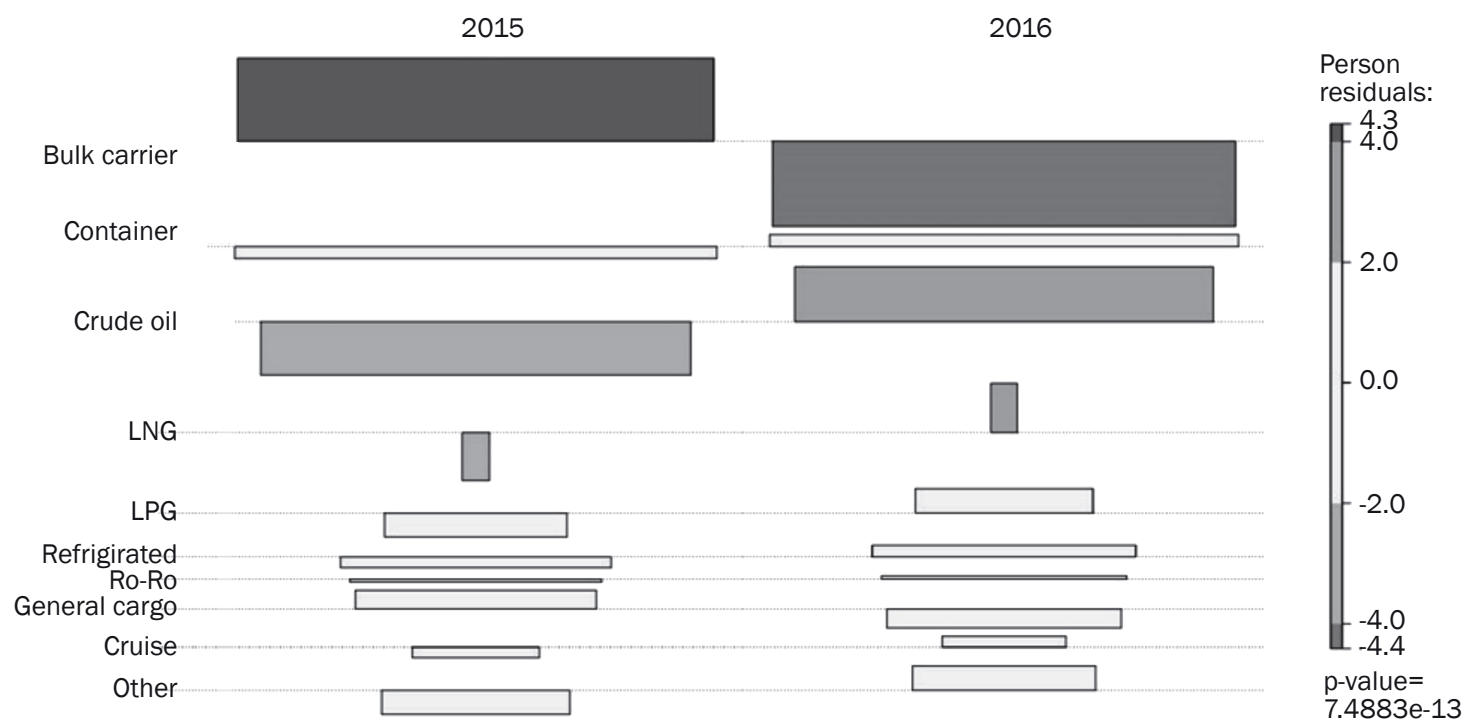

Figure 10 - The "association plot" for the variables 'ship type' and 'transit year', created using " $R$ " statistical software [17] 


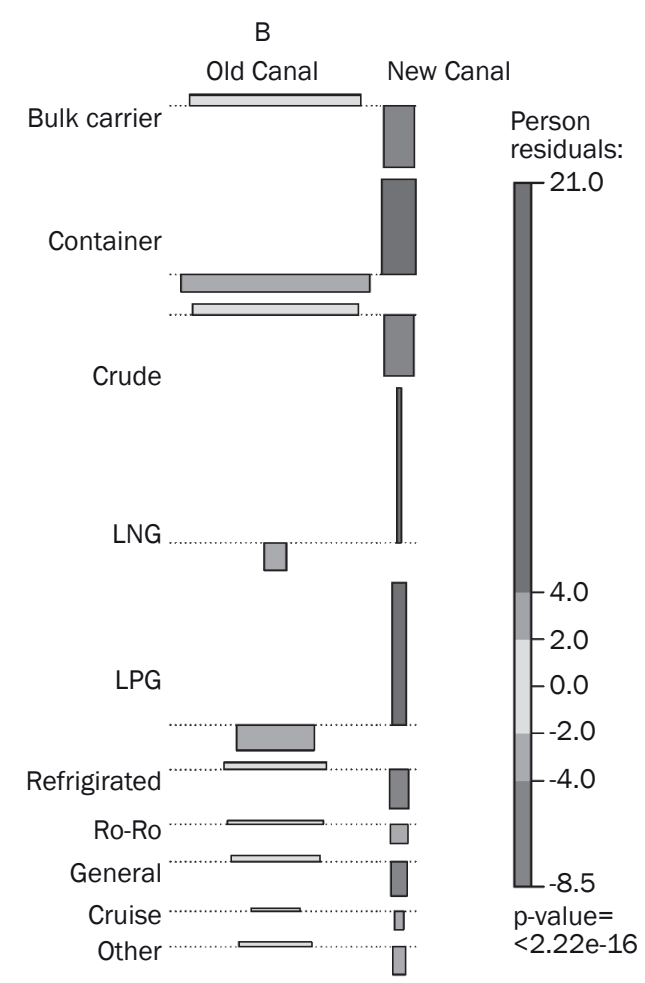

Figure 11 - The "association plot" for the variables largedraft ship type and canal transited (original=old and expanded=new)

ships is significantly higher in the expanded Canal. The number of transits for the remainder of ships is significantly higher in the original Canal.

Greater utilisation of the expanded Canal by container ships (61.6\%) (Figure 9) is a clear indication of the general trend in container maritime shipping of a movement towards larger sized ships, which is the issue that led to the expansion of the Canal (Figure 12). The participation rate for this traffic in terms of total transits is far above the utilisation rates for the unexpanded Canal (24.5\%).

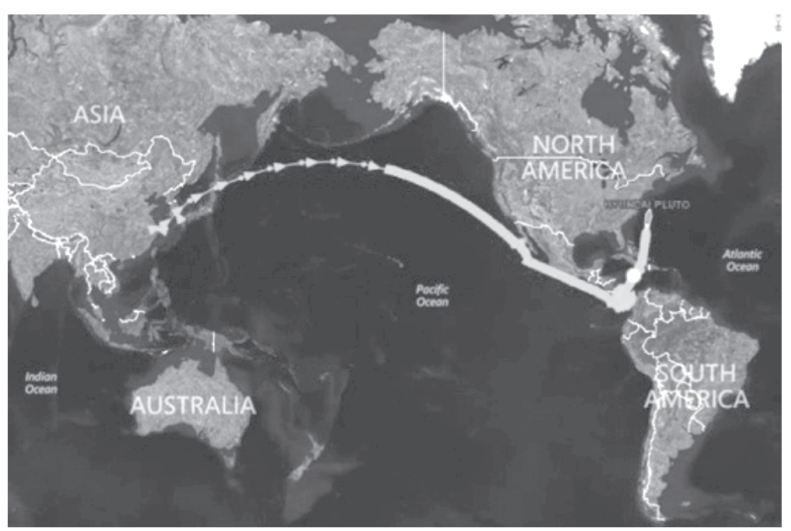

Figure 12 - Hyundai-Pluto (Neopanamax Container vessel of 10,000 TEUs) route, transit on 13 August, heading towards New York

Source: PCA
Another interesting fact is the emergence of unexpected traffic, namely, the transport of liquid gases. Given its significant percentage as part of the total traffic pattern (33.06\%), this represents a surprising development for observers and may have a significant present and future impact. As such, this new traffic could be described as the appearance of a 'black swan' in the operation of the expanded Canal [25]. At the same time, transits by Ro-ro vessels are also significant, and in the near future may lead to the establishment of a clear trend of developing these ships to Neopanamax sizes.

Significantly reduced transit of other ships of importance through the unexpanded Canal, e.g., oil tankers and bulk carriers (1.33\% and 0.8\%, respectively), supports the idea that traffic through the expanded Canal presents a very different paradigm compared to the original Canal.

\subsection{Effect on traffic}

For transits completed during the study time period, it is possible to draw conclusions regarding the routes followed by the ships analysed. These conclusions are presented schematically in Table 3.

\section{EFFECT ON VESSELS}

The impact on vessels is twofold. On the one hand, the factor that can be considered more significant is that a new category of vessel has been created. The main dimensions (length, beam and draft) approach the limits of the locks' dimensions. On the other hand, of lesser consequence, is a change in the safe working load (SWL) and the dimensions of the components used for the towing and mooring systems [4] (PCA, 2016a. p. 73 - Section 30). This involves ensuring there are no protrusions along the sides of the vessel that can slide against the fenders on the chamber wall. These protrusions refer to "anything that sticks out from the hull” [4] (PCA, 2016a. p. 73 - Section 30).

\subsection{Adapting the main dimensions}

Document [4], whose addendum includes section 30, Vessel requirements for the new Panama Canal lock, states that the maximum dimensions for vessels authorised to transit the Canal are $366 \mathrm{~m}$ in length, 49 $\mathrm{m}$ in beam and $15.20 \mathrm{~m}$ in maximum draft [4] (PCA, 2016a. Ch. 30, p. 73).

Given that their beams can be adjusted in accordance with the standard width of the ISO container, the largest Post-Panamax container ships that can use the Canal can have up to 19 rows of containers along the beam, with a nominal loading capacity of up to 13,200 TEUs [33]; [28]. The existing Post-Panamax 
Table 3 - Relationship between traffic/transits, routes and cargo affected for Neopanamax ships - first five months of operation of the expanded Canal

\begin{tabular}{||c|c|l||}
\hline Traffic & Transits & \multicolumn{1}{c|}{ Effect on routes } \\
\hline \hline Containers & $61.6 \%$ & $\begin{array}{l}\text { - New regular services on the Asia-USA east coast route. } \\
\text { - Diversion of containerised cargo from ports on the west coast to the main ports } \\
\text { on the east coast of the USA. }\end{array}$ \\
\hline Liquid gases \\
(LNG - LPG) & $33.1 \%$ & $\begin{array}{l}\text { - Increase in propane and butane (LPG) exports in the USA which are sent from export } \\
\text { terminals located in Houston and are destined for Panama, Guatemala, Chile, } \\
\text { Ecuador, Japan, South Korea and China }\end{array}$ \\
- Commencement of LNG exports from terminals in Houston (USA) destined for \\
$\begin{array}{l}\text { Panama, Guatemala, Chile, Ecuador, Japan, South Korea and China }{ }^{1} \\
\text { - Export of LNG from Trinidad and Tobago to the west coast of South America and to } \\
\text { Asia. } \\
\text { - Use of the Canal route for the export of Peruvian natural gas to Europe. }\end{array}$ \\
\hline Dry bulk & $1.3 \%$ & $\begin{array}{l}\text { - Principal grain route (soya bean and sorghum) from ports in the US Gulf of Mexico to } \\
\text { China, Japan and South Korea } \\
\text { - Coal from Colombia destined for the port of Lazaro Cardenas in Mexico }\end{array}$ \\
\hline Ro-ro & $3.2 \%$ & $\begin{array}{l}\text { - Exports from Japan, South Korea, Mexico, Germany and the United Kingdom to the } \\
\text { USA (east coast and west coast). } \\
\text { - European route (Germany/United Kingdom/Belgium) - US west coast }\end{array}$ \\
\hline Crude & $0.8 \%$ & - From Ecuador destined for the Gulf of Mexico ${ }^{2}$ \\
\hline
\end{tabular}

Source: Author, based on [6, 15]

${ }^{1}$ Natural gas resulting from the exploitation of shale gas through fracking in the USA.

2 Ecuadorian Napo and Oriente crudes are in high demand by North American refineries, given that these types of crude are ideal for mixing with light crudes extracted from shale oil fields in the USA and are being sold at a lower price than WTI (West Texas Intermediate, an oil benchmark in North America). This has created strong incentives for North American refineries to import these types of crude.

vessels with larger dimensions would be relegated to the Asia-Europe route that crosses the Suez Canal [28]. Once the maximum beam permitted in the Canal's locks has been reached, the trend in their growth will follow a process similar to the one studied by Martin et al. [21]: the length/beam (L/B) ratio on the vessel will be increased.

In terms of dry bulk carriers, the Panamax vessels make up most of the world's traffic. In the case of transit through the expanded Canal, the dimensions of these ships will increase until they reach those of a Capesize bulk carrier, whose Gross Registered Tonnage (GRT) is between 120,000 and 150,000 (GRT) $[30,3]$ (PCA, 2006. Ch. 6, p. 19). While this is definitely true of coal and iron ore loads, vessels carrying grain have a draft limitation imposed by terminals of origin in the Gulf of Mexico. In this kind of traffic, one will find vessels with GRT of 95,000 [33, 30].

In traffic involving liquid bulk, such as crude oil and derivatives, it would not be necessary for most vessel categories (Aframax and Suezmax) to be adapted to the dimensions of the new locks [30]. There are no main crude oil routes that cross the Canal [33]. The opposite is true of liquid natural gas (LNG), whose vessel categories are almost exclusively Post-Panamax. With the exception of Q-flex and Q-max type vessels [11] and [7] (Cárdenas-Maldonado, A., Pag. 112), the remaining categories, representing $90 \%$ of the fleet, can use the expanded Canal [33]); [5]. This will lead to a significant level of traffic shown in transit forecasts
[24] when vessels are built in the future, it may be necessary to take into account the maximum dimensions permitted for the 2016 locks. However, the size of these new vessels will mainly be influenced by the need for a balance of transit between the Atlantic and the Pacific zones.

There are two reasons why cruise ships that pass through the Canal arouse world interest. The Canal is a useful route and, on the other hand, it is an attraction in itself for passengers. These vessels have become bigger in recent years; at the same time, there is a high number of Panamax ships. As a result, the guidelines have been extended to embrace the new Neopanamax category. Already, there is a small number of vessels whose operators have opted for a super-sized ship popular for seven to ten-day cruises [3] (PCA, 2006. Ch. 3, p. 52). Nevertheless, this type of vessel will always have a problem when it operates along the Canal in high tide given the current height of the Americas Bridge.

Other types of vessels, like car-carriers and refrigerated ships, will not be affected by their dimensions as these vessels withstand the Canal's limitations without having to make adjustments [3] (PCA, 2006. Ch. 6, p. 40); [7] (Cárdenas-Maldonado, A., 2015, p. 120) (Table 4). The search for new models of Ro-ro operational systems, can, without doubt, lead to an increase in the size of car-carriers [33], so that they reach Neopanamax dimensions. 
Table 4 - Effect of the expansion on vessel size. The most commonplace vessel sizes in the main traffic crossing the newly expanded $P C$

\begin{tabular}{|c|c|c|}
\hline Traffic & Sub-traffic & Vessel size used in PC \\
\hline \multirow{2}{*}{$\begin{array}{l}\text { Solid } \\
\text { bulk }\end{array}$} & Coal - Iron ore & "Mini cape-size ${ }^{1}$ \\
\hline & Grain & Mini cape-size ${ }^{2}$ \\
\hline \multirow{2}{*}{$\begin{array}{l}\text { Liquid } \\
\text { bulk }\end{array}$} & Crude oil & Aframax \\
\hline & LNG - LPG & Most of the existing ones ${ }^{3}$ \\
\hline \multirow{2}{*}{$\begin{array}{l}\text { General } \\
\text { cargo }\end{array}$} & Pure Car Carrier & Neopanamax 4 \\
\hline & Container & Neopanamax ${ }^{4}$ \\
\hline Cruisers & $\begin{array}{l}\text { Tourist cruise } \\
\text { ships }\end{array}$ & Neopanamax 4 \\
\hline
\end{tabular}

Source: Author, based on [33, 30]

1 Traffic in terms of a 120,000 GRT bulk carrier

2 Traffic in terms of a 95,000 GRT bulk carrier

${ }^{3}$ All categories with the exception of Q-flex and Q-max vessels

${ }^{4}$ Ship adapted in its principal dimensions to the new locks

\subsection{Layout of towing system components}

As for the systems needed for mooring, as well as forecastle and poop deck towing manoeuvres, there are guidelines in [2] about the activities related to sailing in the waters found within the Canal's area of compatibility. These regulations were revised for the newly expanded canal [4]. They deal with mooring components. The bollard bitt and chocks are located on the forecastle and poop deck (Table 5) for the operating system driven by train engines and the locks' tugboats pulling and centring the vessel throughout the entire transit.

Table 5 - SWL and dimensions of the chocks and bitts involved in lock transit manoeuvres

\begin{tabular}{||l|c|c||}
\hline & \multicolumn{2}{|c|}{ Safe Working Loads (SWL) in T-f } \\
\hline \hline Deck component & 1,914 locks & 2,016 locks \\
\hline Double chocks & 64 & 90 \\
\hline Simple chock & 45 & 90 \\
\hline Bollard bitt & 45 & 90 \\
\hline \hline & \multicolumn{2}{|c|}{ Diameter [mm] } \\
\hline \hline Bollard bitt & 356 & 500 \\
\hline
\end{tabular}

Table 5 shows the Safe Working Load (SWL) and dimensions of the chocks and bitts involved in lock transit manoeuvres, in accordance with the regulations for navigating in PC waters [4], positioned according to the table on chocks and bitts [4] (PCA, 2016a. p. 42) for the original 1914 PC. Changes were made for transit through the locks of the expanded Canal [4] (PCA, 2016a. p. 73)

\subsection{Eliminating protrusions on the vessel's hull}

As for the maximum dimensions of the vessels transiting the expanded Canal, section 30 [4] determines these values. This text also establishes that "vessels with protrusions will only be able to transit if these protrusions do not compromise safety or do not put the canal's infrastructure at risk, according to guidelines set by its Authority". It is therefore important to point out that the manoeuvre for moving between the locks' chambers can be carried out if the vessel rests on the fenders found along the chamber walls. In this kind of operation, the Canal staff have to be extremely meticulous when they look out for and inspect any components that protrude from the hull. These may be a protrusion that could possibly jeopardise the chamber wall's fender [4] (PCA, 2016a. Ch. 30- p. 80). In any case, it will be necessary to eliminate these protruding components before the transit.

\section{CONCLUSIONS}

For vessel transits completed in the original Canal in recent years, the indication is that these variables (number of transits for ship type and year) are independent for all traffic, with the exception of bulk carriers and oil tankers.

The statistical analysis confirms that the number of transits for container, LNG and LPG vessels is significantly higher in the expanded Canal, whereas the number of transits for the remainder of ships is significantly higher in the original Canal.

With respect to transits through the expanded Canal, container transport (representing $61.6 \%$ of total traffic) comprises the largest volume of goods, which confirms the expectations that prompted the expansion of the Canal. The use of larger sized ships on the Asia-US East Coast route creates an additional competitive factor for this route when compared to the American Intermodal System or the Suez Canal route.

The commencement of commercial exploitation of shale gas fields in the USA and Trinidad and Tobago, together with the increased demand for LNG in Asia, place the Canal in the position of regulating exchanges of LNG/LPG between the Pacific and the Atlantic maritime areas. In the concrete case of LNG, the shipping fleet is generally of the Post-Panamax size, which has led to the emergence of this type of traffic in the Canal, and makes these transits the second highest (at 33.1\%) in terms of traffic through the expanded Canal.

For wheeled cargo traffic (Ro-ro), a small but significant figure (3.2\%), which is close to the total for the Canal (6.1\%), could place automobile distribution logistics and this type of vessel in a position of having future growth prospects similar to those experienced in the world of container ships.

The preceding points demonstrate that the traffic pattern for the expanded Canal bears no relation to the pattern observed in recent years for the unexpanded Canal. 
With respect to ships, expanding the Canal will undoubtedly mean that a new kind of vessel comes into existence; a similar phenomenon occurred with the original Canal. In terms of dimensions, these Neopanamax ships will be adapted to how the locks operate. However, this effect will not be the same across the full range of traffic. With container ships, the impact has been felt since 2006, when it became known which expansion plan had been chosen. As a result, there was a steady stream of orders for container ships; these took into account the dimensions of the locks being designed. Over time, the impact will grow so that the main dimensions of length, beam and draft would fall within the parameters established for the locks. With car-carriers and liquid natural gas (LNG) tankers, a similar effect will be produced. However, the size of solid and liquid bulk carriers and cruise ships remains unaffected, using the Panamax vessel. A further, less significant effect is experienced with changes in the safe working load (SWL), as well as in the dimensions of components involved in towing and mooring manoeuvres. For these manoeuvres, it is necessary to ensure that the surface of the vessel's flanks sliding along the chamber wall fenders have no protrusions.

\section{Dr. LUIS CARRAL ${ }^{1}$}

E-mail: Icarral@udc.es

Dr. JAVIER TARRÍO-SAAVEDRA ${ }^{1}$

E-mail: jtarrio@udc.es

\section{Dr. LAURA CASTRO-SANTOS}

E-mail: laura.castro.santos@udc.es

Dr. ISABEL LAMAS-GALDO ${ }^{1}$

E-mail: isabel.lamas.galdo@udc.es

Dr. RODOLFO SABONGE ${ }^{2}$

E-mail: rodosabochamo@gmail.com

${ }^{1}$ EPS Ferrol, Universidade da Coruña

Campus de Esteiro, Rúa Mendizábal s/n, 15403 Ferrol, España

2 Universidad Marítima Internacional de Panamá La Boca, Edif. 1033, Corregimiento de Ancón, Panamá, P.O. Box 0843-03561, Panama

\section{EFECTO DE LA PUESTA EN SERVICIO DEL TERCER JUEGO DE ESCLUSAS DEL CANAL DE PANAMÁ SOBRE EL TAMAÑO DE LOS BUQUES Y EL TRANSPORTE MARITIMO}

\section{ABSTRACT}

La ampliación del Canal de Panamá (CP) incide en los patrones del comercio y en la forma en que las mercancias se transportan alrededor del mundo. Con la puesta en marcha de la solución de ampliación adoptada, consistente en la construcción de un tercer juego de esclusas, la metodología general en el tránsito de los buques Neopanamax en el Canal ampliado se mantiene, pero con unas dimensiones y una operativa en las esclusas diferentes que afectan tanto al tamaño de los buques como a su maniobra. Sin embargo este efecto no será el mismo en todos los tráficos que circulan por el Canal. Tras la inauguración del Canal ampliado el 26 de junio de 2016 se han empezado a recopilar datos de tiempo de tránsito que conviene interpretar en profundidad mediante el correspondiente análisis estadístico. De este análisis se extraen conclusiones sobre el modo que las nuevas esclusas impactan sobre el tamaño de los buques y el transporte marítimo.

\section{PALABRAS CLAVE}

Proyecto del Canal de Panamá ampliado; buques, análisis estadístico; comercio marítimo; tráficos;

\section{REFERENCES}

[1] Alemán Zubieta A. Lecciones aprendidas ampliación del Canal. Panamá: Foro - Ciudad del Saber; 2016. Spanish

[2] Autoridad del Canal de Panamá (PCA). Reglamento para la navegación en aguas del PC- 3 de junio de 1999. Spanish

[3] Autoridad del Canal de Panamá (PCA). Plan Maestro 2005-25. Available from: www.pancanal.com [Accessed July 2016]. Spanish

[4] Autoridad del Canal de Panamá (PCA), 2016a. Vessel Requirements - Notice to shipping $N^{\circ}-1-2016$.

[5] Autoridad del Canal de Panamá (PCA), 2016b. Primer buque de GNL transita por el Canal ampliado. Available from: http://micanaldepanama.com/primer-buque-de-GNL-transita-por-el-canal-ampliado/ [Accessed July 2016]. Spanish

[6] Autoridad del Canal de Panamá (PCA), 2016c. Informe anual 2015. Available from: https://micanaldepanama.com/wp-content/uploads/2012/InformeAnual/ Informe-Anual-2015.pdf [Accessed Dec 2016].

[7] Cárdenas-Maldonado A. Efectos de la ampliación del Canal de Panamá sobre el Comercio y el Tráfico Marítimo Internacional. Repositorio de la Universidad Politécnica de Valencia. 2015. Available from: https:// riunet.upv.es/bitstream/handle/10251/52657/01_ Memoria.pdf?sequence=1 [Accessed July 2016]. Spanish

[8] Carral L, Tarrío-Saavedra J, Naya S, Bogle J, Sabonge R. Effect of inaugurating the third set of locks at the Panama Canal on vessel size, manoeuvring and lockage time. The Journal of Navigation. 2017;70: 120523.

[9] Cohen A. On the Graphical Display of the Significant Components in a Two-Way Contingency Table. Communications in Statistics-Theory and Methods. 1980;A9: 1025-1041.

[10] Cope III, R. Cope R. Woosley J. Container Ship Routing: Panama Canal vs. U.S. Land Bridge. Journal of Management Policy and Practice. 2016;17(1): 89-93.

[11] Cota-Mascuñana D, Castro-Ponte A, Carballo Sánchez R, Carral Couce L, Fraguela Formoso JA. O comercio marítimo. Santiago, España: Servicio de Publicacións da Universidade de Santiago de Compostela; 2015. Galician

[12] Cullinane $\mathrm{K}$, Khanna M. Economies of scale in large container ships: Optimal size and geographical implication. Journal of Transport Geography. 2000;8(3): 181-195.

[13] Ducruet C. The polarization of global container flows by interoceanic canals: geographic coverage and 
network vulnerability. Maritime Policy \& Management. 2016;43(2): 242-260.

[14] Encyclopaedia Britannica. Panama Canal. Available from: https://www.britannica.com/topic/Panama-Canal [Accessed June 2016].

[15] Faro. 2016. Haciendo historia: El tránsito por el canal ampliado. $\mathrm{n}^{\circ}$ 100. 2016. Available from: http://micanaldepanama.com/wp-content/uploads/2016/10/ elfaro-201601031.pdf [Accessed Dec 2016]. Spanish

[16] Guevara-Martínez V. Análisis de la Capacidad Operativa del Canal Actual y Ampliado, en Función de la Cantidad de Tránsitos. Repositorio UVA; 2013. Available from: https://uvadoc.uva.es/bitstream/10324/7078/1/ TFM-P-116.pdf [Accessed July 2016]. Spanish

[17] Hornik K, Zeileis A, Meyer D. The strucplot framework: visualizing multi-way contingency tables with vcd. Journal of Statistical Software. 2007;17(3): 1-48.

[18] Huebner GG. Economic aspects of the Panama Canal. Am. Econ. 1915;5(4): 816-829.

[19] Jaén O, Alvarado C. The Panama Canal. Panama: Ed. Balboa; 1999.

[20] Lindstad H, Jullumstro E, Sandaas I. Reductions in cost and greenhouse gas emissions with new bulk ship designs enabled by the Panama Canal expansion. Energy Policy. 2013;59: 341-349.

[21] Martin J, Martin S, Pettit S. Container ship size and the implications on port call Workload. Int. J. Shipping and Transport Logistics. 2015;7(5): 553-569.

[22] Mitchell CW. Impact of the expansion of the Panama Canal: an engineering analysis; 2011. Available from: https://www.ce.udel.edu/.../Mitchell\%20-\%20Impact\%20of\%20th [Accessed July 2016].

[23] Montero Llacer FJ. The Panama Canal: operations and traffic. Marine Policy. 2005;29: 223-234.

[24] Moryadee S, Gabriel SA, Rehulka F. The influence of the Panama Canal on global gas trade. Journal of Natural Gas Science and Engineering. 2014;20: 161-174.

[25] Nassim Taleb N. The Black Swan: The Impact of the Highly Improbable. New York Times; 2011.

[26] Notteboom TE, Rodrigue J-P. Challenges to and Challengers of the Suez Canal. Port Technology International 51. 2011;51: 14-17. Available from: http://www. porttechnology.org/images/uploads/technical_papers/PT51-11.pdf [Accessed Nov 2013].

[27] Pagano A, Zou B, Sanchez O. The Demand and Supply of Trans-Oceanic Sea Routes: The Case of East Asia-US East Coast Container Trade. Proceedings of the ECONSHIP2015 Conference, June. Chios, Greece; 2015.

[28] Pagano A, Wang G, Sánchez O, Ungo R, Tapiero E. The impact of the Panama Canal expansion on Panama's maritime cluster. Maritime Policy \& Management. 2016;43(2): 164-178.

[29] Polo G, Carlier M, Seco E. Temas de Tráfico Marítimo. Universidad Politécnica de Madrid; 2016.

[30] Riva Francos J. La ampliación del Canal, ¿Una oportunidad para los navieros europeos? In: Monografia. Seminario Internacional: Canal de Panamá: El reto de la ampliación de la vía interoceánica o cómo diseñar, construir y gestionar una de las obras de ingeniería más grandes del mundo. Madrid, España; 2011. Available from: http://www.fundacionareces.es/fundacionareces/portal.do?TR=C\&IDR=1032 [Accessed Dec 2016]

[31] Rodrigue J-P, Ashar A. Transshipment hubs in the New Panamax Era: The role of the Caribbean. Journal of Transport Geography. 2016;51: 270-277.

[32] Sabonge R. El Comercio Marítimo. In: Monografia. Seminario Internacional: Canal de Panamá: El reto de la ampliación de la vía interoceánica o cómo diseñar, construir y gestionar una de las obras de ingeniería más grandes del mundo. Madrid, España; 2011. Available from: http://www.fundacionareces.es/fundacionareces/portal.do?TR=C\&IDR=1032 [Accessed December 2016]. Spanish.

[33] Sabonge R. La ampliación del Canal de Panamá. Impulsor de cambios en el comercio internacional. Naciones Unidas - Comisión Económica para América Latina y el Caribe (CEPAL); 2014. Spanish.

[34] Stopford M. Maritime Economics. $3^{\text {rd }}$ Ed. Oxon: Routledge; 2009.

[35] Ungo R, Sabonge R. A competitive analysis of Panama Canal routes. Maritime Policy and Management. 2012;39(6): 555-570. 